Journal of the Egyptian Society of Parasitology, Vol.43, No.2, August 2013 J. Egypt. Soc. Parasitol., 43(2), 2013: 517 - 526

\title{
FATTY ACIDS CONTENTS IN BIOMPHALARIA ALEXANDRINA DURING THE COURSE OF INFECTION WITH SCHISTOSOMA MANSONI
}

\author{
By \\ MOMEANA B. MAHMOUD, KAMELIA EL-SAYED AND \\ AHMED T.SHARAF EL-DIN \\ Department of Medical Malacology, Theodor Bilharz Research Institute, \\ Imbaba 30, Giza, Egypt
}

\begin{abstract}
The study examined the effects of larval trematode infection on the neutral lipid and phospholipid content of Biomphalaria alexandrina infected with Schistosoma mansoni. Uninfected snails were used as matched controls. As determined by qualitative high-performance silica gel thin-layer chromatography (HPTLC), the major neutral lipids present in the whole bodies and digestive gland-gonad complexes in both infected and uninfected snail populations were free sterols, free fatty acids, and triacylglycerols, and the major polar lipids were phosphatidylcho-line and phosphatidyl ethanolamine. Quantitative analysis by HPTLC with visible and UV scanning reflectance densitometry showed the snail's digestive gland lipid level was found to be almost halved in 20 days post infection; a more then $80 \%$ reduction being visible after the subsequent 40 and 60 days.

Key Words: Egypt, Biomphalaria alexandrina, fatty acids, Schistosoma mansoni

\section{Introduction}

Schistosoma mansoni infections in Biomphalaria snails alter the quality and quantity of lipids in this snail host (Massa et al, 2007). For instance, Thompson (1997) found that B. glabrata infected with $S$. mansoni had significantly higher levels of triacylglycerols in the digestive gland-gonad complex (DGG) than that of uninfected control snails. By the using of the B. glabrata$S$. mansoni model, Muller et al. (2000) found that at 8 weeks post-infection, the concentrations of the free sterols and triacylglycerols in the infected DGG increased about two times compared to the uninfected control snails. Thompson et al. (1991) analyzed neutral lipids and phospholipids in the

DGGs of uninfected B. glabrata and infected with $S$. mansoni found reduced levels of phosphatidylcholine and several other phospholipids in the DGGs infected snails. Fried et al.(1989) determined the effects of larval $E$. caproni infection on the neutral lipid content of the DGG in B. glabrata and found that the triacylglycerols, steryl esters, and free fatty acids were elevated in control DGGs compared to those in infected ones. Perez et al. (1994) analyzed the phospholipids in the DGG of B. glabrata infected with E. caproni and found that the mean weight percentage of phosphatidylserine was 1.5 times greater in the DGG of infected vs uninfected snails.

Tunholi-Alveset al.(2011) studied the
\end{abstract}


effect of Biomphalaria glabrata exposure to different doses (5\&50) of Echinostoma paraensei miracidia on the total levels of cholesterol and triglycerides circulating in the hemolymph and the neutral lipids in the digestive gland-gonad (DGG) complex. The snails were dissected one, two, three and four weeks after infection to collect the hemolymph and DGG tissue, to measure the levels of cholesterol and triglycerides in the hemolymph and neutral lipids in the tissue. The hemolymph showed a similar order of variation for both substrates tested in the first week after infection. The lipids reduced levels in the infected snails indicated intense use of these substrates both by the intermediate host and the parasite, suggesting its probable participation in the energy metabolism and structural construction of the developing larval stages. Alterations in the profile of neutral lipids in the DGG were also found. The results obtained indicate that in this model, the lipid metabolism depends on the miracidial dose used (Fried et al, 2001).

Beers et al. (1995) analyzed the effects of E. caproni infection on B. glabrata. An analysis of the snails fed a hen's egg yolk-lettuce mixed diet showed that the triacylglycerols were significantly reduced in the DGGs of infected snails, whereas the free sterols were significantly elevated in the DGGs of infected snails. The triacylglycerol level was reduced but not significantly different in the DGGs of infected vs uninfected snails. DGGs with daughter rediae of E. caproni were used as samples, but snails the infec- tion was pre-patent. The conflicting of some results in the previous studies on lipid content in Biomphalaria infected with $S$. mansoni, initiates this research to examine using high-performance TLC (HPTLC) analysis on infected snails and matched controls. So, this study focus on neutral lipid and phospholipid analysis of $B$. alexandrina infected with $S$. mansoni under conditions of controlled miracidial infection and snail diet.

\section{Materials and Methods}

Snail infection: Group of 90 juvenile Biomphalaria alexandrina $(3-5 \mathrm{~mm}$ in diameter) was exposed individually to 10 newly hatched miracidia of Schistosoma mansoni obtained from Schistosome Biological Supply Project, Theodor Bilharz Research Institute, in vials containing $3 \mathrm{ml}$ dechlorinated water for 3-4 hours. After that, snails were gathered in 3 aquaria containing dechlorinated water and food was presented as dry oven lettuce leaves and water was changed three times a week. Exposed snails were used $10,20 \& 30$ days post miracidial exposure in HPTLC studies. Another group of uninfected (50 snails) cross-matched snails served as a control was prepared for HPTLC analysis as previously described.

Snails in G1 (infected) and G2 (control) were divided into two subgroups. In the first subgroup, whole bodies of snails were obtained by carefully removing the shells with needles and forceps. Digestive gland-gonad complexes (DGG) were removed from the remaining viscera and placed into test tubes containing $10 \mathrm{ml}$ chloroform: methanol (1:1) mixture, covered with a lid and 
placed in a refrigerator $\left(5^{\circ} \mathrm{C}\right)$ until needed. Three DGG were pooled per sample.

In the second subgroups, hemolymph was obtained by cracking the shell in a Petri dish, tipping the dish, and collecting the hemolymph from the edge with a pipette. Hemolymph from three snails was pooled to prepare one sample of about $100 \mu$ l. Plasma (hemolymph minus hemocytes) was obtained after centrifuging the hemolymph for $6 \mathrm{~min}$ at $5000 \times g$ and separating the top layer (plasma) from the pellet (hemocytes and debris). The pellet was discarded.

Lipids were extracted from the digestive gland (Folch et al, 1957) using a chloroform: methanol (1:1) mixture, then separated into fractions of triglycerids (triacetin) and phospholipids by thin-layer chromatography on silica gel in a mixture of hexane: ether: acetic acid (73:25:2). Chromatograms were developed in iodine vapour. Separated fractions of lipids were exposed to alkaline methanolysis, and fatty acid methyl esters were separated by gas-liquid chromatography using a Pye 104 model 24 gas chromatograph. Identification of individual fatty acids was made by comparing the relative retention time of standard fatty acids and their mass spectra, revealed by gas chromatograph-mass spectrometry. The fatty acid content was estimated as the area under a peak computed by triangulation. The data were expressed as the percentage of the sum of all fatty acids of the given lipid fraction. The plasma was processed by the same procedure as the digestive gland.
Gas chromatography (GC): FAMEs were separated and quantified by capillary gas chromatography. The chromatography system consisted of a Hewlett Packard gas chromatograph (model 6890), a flame ionization detector, and Hewlett-Packard Chem Station software. The injection port and the detector temperatures were $270^{\circ} \mathrm{C} \& 280^{\circ} \mathrm{C}$, respectively. The split ratio was 1:20. The flow rates of compressed air and hydrogen were $300 \mathrm{~mL} / \mathrm{min}$ and 30 $\mathrm{mL} / \mathrm{min}$, respectively. Helium was used as carrier gas $(2.8 \mathrm{~mL} / \mathrm{min})$. The oven temperature was programmed at a rate of $6.5^{\circ} \mathrm{C} / \mathrm{min}$ from $130^{\circ} \mathrm{C}(1 \mathrm{~min}$ hold) to $170^{\circ} \mathrm{C}$, increased to a rate of $2.75^{\circ} \mathrm{C} / \mathrm{min}$ to $215^{\circ} \mathrm{C}$, again increased to a rate of $40^{\circ} \mathrm{C} / \mathrm{min}$ to $230^{\circ} \mathrm{C}$, was held for $12 \mathrm{~min}$. Total fatty acids levels and spectra of FAMEs are obtained by HP 3365 Chem Station computer program. Chemical structures of FAMEs were determined by analyses of spectra and by comparing obtained spectra with the spectra of authentic standards (Sigma-Aldrich Chemicals). Individual FAME was identified by comparison with the chromatographic behaviors of authentic standards (Sigma-Aldrich Chemicals).

Statistical analysis: Analyses were performed using SPSS (12.0). Percentages of fatty acids were tested by analysis of variance (ANOVA) and comparisons between means were performed with Tukey's test. The differences between means were considered to be significant whenever $\mathrm{P}<0.05$.

\section{Results}

The results are shown in tables $(1,2,3$ \& 4). 
Table 1: Fatty acid contents in phospholipids of $B$. alexandrina infected with $S$. mansoni (expressed as \% of total phospholipid fatty acids).

\begin{tabular}{|c|c|c|c|c|}
\hline \multirow{3}{*}{$\begin{array}{l}\text { Fatty } \\
\text { Acids }\end{array}$} & \multirow{3}{*}{$\begin{array}{c}\text { Control } \\
\text { Mean* } \pm \text { S.E. ** }\end{array}$} & \multicolumn{3}{|c|}{ Exposed snails to miracidia after } \\
\hline & & 10 days & 20 days & 30 days \\
\hline & & Mean* \pm S.E. $* *$ & Mean* \pm S.E. $* *$ & Mean* \pm S.E. **) \\
\hline C12:0 & $0.29 \pm 0.03 a$ & - & - & $0.10 \pm 0.01 \mathrm{a}$ \\
\hline C14:0 & $1.70 \pm 0.11 \mathrm{a}$ & - & - & $1.50 \pm 0.11 \mathrm{a}$ \\
\hline $\mathrm{C} 15: 0$ & $0.47 \pm 0.14 \mathrm{a}$ & $0.43 \pm 0.13 a$ & $0.70 \pm 0.26 \mathrm{a}$ & $0.80 \pm 0.04 a$ \\
\hline C16:0 & $20.95 \pm 1.24 \mathrm{a}$ & $20.30 \pm 1.24 \mathrm{a}$ & $24.06 \pm 1.23 \mathrm{~b}$ & $30.02 \pm 1.29 \mathrm{c}$ \\
\hline C17:0 & $0.46 \pm 0.04 \mathrm{a}$ & $0.50 \pm 0.04 \mathrm{a}$ & $2.54 \pm 0.18 \mathrm{~b}$ & $0.50 \pm 0.02 \mathrm{a}$ \\
\hline C18:0 & $8.68 \pm 0.75 a$ & $9.01 \pm 0.85 \mathrm{a}$ & $11.72 \pm 0.94 \mathrm{a}$ & $11.41 \pm 0.96 \mathrm{a}$ \\
\hline$\sum$ SFA & $32.55 \pm 1.42 \mathrm{a}$ & $30.24 \pm 1.41 \mathrm{a}$ & $39.02 \pm 1.75 b$ & $44.33 \pm 1.95 \mathrm{c}$ \\
\hline $\mathrm{C} 16: 1 \omega 7$ & $3.60 \pm 0.35 \mathrm{a}$ & $7.12 \pm 0.69 b$ & $14.70 \pm 1.16 \mathrm{c}$ & $3.95 \pm 0.32 \mathrm{a}$ \\
\hline $\mathrm{C} 18: 1 \omega 9$ & $35.46 \pm 1.40 \mathrm{a}$ & $33.11 \pm 1.48 \mathrm{a}$ & $18.13 \pm 1.19 \mathrm{~b}$ & $13.02 \pm 1.21 \mathrm{c}$ \\
\hline $\mathrm{C} 20: 1 \omega 9$ & $0.31 \pm 0.02 \mathrm{a}$ & $0.38 \pm 0.03 \mathrm{a}$ & $0.52 \pm 0.05 \mathrm{a}$ & $3.12 \pm 0.31$ \\
\hline$\sum$ MUFA & $39.37 \pm 1.62 \mathrm{a}$ & $40.41 \pm 1.85 \mathrm{a}$ & $33.35 \pm 1.39 \mathrm{~b}$ & $20.09 \pm 1.23 c$ \\
\hline $\mathrm{C} 18: 2 \omega 6$ & $16.02 \pm 1.12 \mathrm{a}$ & $20.10 \pm 1.28 b$ & $9.03 \pm 0.87 \mathrm{c}$ & $13.05 \pm 1.22 \mathrm{~d}$ \\
\hline $\mathrm{C} 18: 3 \omega 3$ & $3.06 \pm 0.29 \mathrm{a}$ & $2.33 \pm 0.25 a$ & $3.84 \pm 0.32 \mathrm{a}$ & $5.82 \pm 0.53 b$ \\
\hline $\mathrm{C} 20: 2 \omega 6$ & $1.02 \pm 0.11 \mathrm{a}$ & $1.11 \pm 0.09 a$ & $1.13 \pm 0.08 \mathrm{a}$ & $2.11 \pm 0.22 b$ \\
\hline $\mathrm{C} 20: 4 \omega 6$ & $3.70 \pm 0.31 \mathrm{a}$ & $3.92 \pm 0.29 a$ & $7.09 \pm 0.72 b$ & $8.07 \pm 0.82 b$ \\
\hline $\mathrm{C} 20: 5 \omega 3$ & $3.76 \pm 0.35 \mathrm{a}$ & $2.02 \pm 0.18 b$ & $6.60 \pm 0.74 c$ & $5.03 \pm 0.49 \mathrm{~d}$ \\
\hline 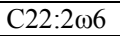 & - & - & - & $1.50 \pm 0.09$ \\
\hline$\sum$ PUFA & $27.56 \pm 1.35 \mathrm{a}$ & $29.33 \pm 1.26 \mathrm{a}$ & $27.59 \pm 1.25 \mathrm{a}$ & $35.58 \pm 1.44 b$ \\
\hline
\end{tabular}

Means averages of 3 replicates of 1 sample. Values $=$ mean \pm S.E. $* *$ Means with same letter in each row do not significantly differ from each other, $P>0.05$. SFA: Saturated Fatty Acids, MUFA: Monounsaturated Fatty Acids, PUFA: Polyunsaturated Fatty Acids

Table 2: Fatty acid contents in neutral lipids of B. alexandrina infected with $S$. mansoni (expressed as \% of total neutral lipids fatty acids).

\begin{tabular}{|c|c|c|c|c|}
\hline \multirow{3}{*}{$\begin{array}{l}\text { Fatty } \\
\text { Acids }\end{array}$} & \multirow{3}{*}{$\begin{array}{c}\text { Control } \\
\text { Mean* } \pm \text { S.E. ** }\end{array}$} & \multicolumn{3}{|c|}{ Exposed snails to miracidia after } \\
\hline & & 10 days & 50 days & 40 days \\
\hline & & Mean* \pm S.E. $* *$ & Mean* \pm S.E. ** & Mean* \pm S.E. ** \\
\hline C10:0 & $0.66 \pm 0.06 \mathrm{a}$ & - & - & $1.10 \pm 0.10 \mathrm{~b}$ \\
\hline C12:0 & $0.74 \pm 0.07 \mathrm{a}$ & $0.12 \pm 0.01 \mathrm{a}$ & $0.57 \pm 0.05 \mathrm{a}$ & $2.03 \pm 0.20 \mathrm{~b}$ \\
\hline C13:0 & $0.71 \pm 0.07 \mathrm{a}$ & $0.20 \pm 0.02 \mathrm{a}$ & $3.12 \pm 0.28 b$ & $3.75 \pm 0.28 b$ \\
\hline $\mathrm{C} 14: 0$ & $4.04 \pm 0.38 \mathrm{a}$ & $2.00 \pm 0.21 \mathrm{~b}$ & $4.24 \pm 0.39 \mathrm{a}$ & $4.63 \pm 0.36 \mathrm{a}$ \\
\hline C15:0 & $1.38 \pm 0.12 \mathrm{a}$ & $1.60 \pm 0.12 \mathrm{a}$ & $2.19 \pm 0.20 \mathrm{~b}$ & $1.62 \pm 0.14 \mathrm{a}$ \\
\hline C16:0 & $19.85 \pm 1.25 \mathrm{a}$ & $22.08 \pm 1.25 \mathrm{~b}$ & $24.21 \pm 1.32 b$ & $27.90 \pm 1.33 \mathrm{c}$ \\
\hline C17:0 & $0.68 \pm 0.05 a$ & $2.30 \pm 0.28 b$ & $3.00 \pm 0.25 \mathrm{c}$ & $1.68 \pm 0.14 \mathrm{~d}$ \\
\hline C18:0 & $7.36 \pm 0.68 \mathrm{a}$ & $4.33 \pm 0.29 b$ & $10.26 \pm 0.90 \mathrm{c}$ & $7.08 \pm 0.68 \mathrm{a}$ \\
\hline$\sum$ SFA & $35.42 \pm 1.43 \mathrm{a}$ & $32.63 \pm 1.120 \mathrm{a}$ & $47.59 \pm 2.23 b$ & $49.79 \pm 2.30 \mathrm{~b}$ \\
\hline $\mathrm{C} 16: 1 \omega 7$ & $7.21 \pm 0.65 \mathrm{a}$ & $5.47 \pm 0.56 \mathrm{~b}$ & $6.18 \pm 0.58 \mathrm{c}$ & $7.49 \pm 0.71 \mathrm{a}$ \\
\hline 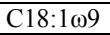 & $16.99 \pm 1.20 \mathrm{a}$ & $36.20 \pm 2.16 b$ & $17.60 \pm 1.25 \mathrm{a}$ & $7.84 \pm 0.75 c$ \\
\hline $\mathrm{C} 20: 1 \omega 9$ & $6.14 \pm 0.55 \mathrm{a}$ & $4.10 \pm 0.35 b$ & $0.73 \pm 0.08 \mathrm{c}$ & $2.28 \pm 0.24 \mathrm{~d}$ \\
\hline$\sum$ MUFA & $30.34 \pm 1.42 \mathrm{a}$ & $45.47 \pm 2.21 \mathrm{~b}$ & $24.51 \pm 1.31 \mathrm{c}$ & $17.61 \pm 1.20 \mathrm{~d}$ \\
\hline 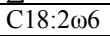 & $11.84 \pm 0.96 \mathrm{a}$ & $15.56 \pm 1.10 \mathrm{~b}$ & $12.10 \pm 0.85 a$ & $10.50 \pm 0.85 a$ \\
\hline $\mathrm{C} 18: 3 \omega 3$ & $7.56 \pm 0.68 \mathrm{a}$ & $2.10 \pm 0.16 \mathrm{~b}$ & $10.92 \pm 0.80 \mathrm{c}$ & $15.40 \pm 1.18 \mathrm{~d}$ \\
\hline $\mathrm{C} 20: 2 \omega 6$ & $1.94 \pm 0.11 \mathrm{a}$ & $0.71 \pm 0.07 \mathrm{~b}$ & $0.54 \pm 0.06 \mathrm{~b}$ & $1.64 \pm 0.12 \mathrm{a}$ \\
\hline $\mathrm{C} 20: 3 \omega 6$ & $1.31 \pm 0.10 \mathrm{a}$ & - & - & - \\
\hline 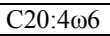 & $5.92 \pm 0.57 \mathrm{a}$ & $1.48 \pm 0.10 \mathrm{~b}$ & $1.94 \pm 0.11 \mathrm{~b}$ & $3.53 \pm 0.32 \mathrm{c}$ \\
\hline $\mathrm{C} 20: 5 \omega 3$ & $4.70 \pm 0.41 \mathrm{a}$ & $2.10 \pm 0.32 b$ & $2.18 \pm 0.20 \mathrm{~b}$ & $2.33 \pm 0.22 b$ \\
\hline $\mathrm{C} 22: 2 \omega 6$ & - & - & - & $0.20 \pm 0.02$ \\
\hline $\mathrm{C} 22: 6 \omega 3$ & $1.86 \pm 0.10 \mathrm{a}$ & - & - & - \\
\hline$\sum$ PUFA & $35.13 \pm 1.48 \mathrm{a}$ & $21.95 \pm 1.29 b$ & $27.68 \pm 1.39 c$ & $33.60 \pm 1.38 \mathrm{a}$ \\
\hline
\end{tabular}


Table 3: Fatty acid contents in total body lipids of B.alexandrina infected with $S$. mansoni (expressed as \% of total body lipids fatty acids).

\begin{tabular}{|c|c|c|c|c|}
\hline \multirow{3}{*}{$\begin{array}{l}\text { Fatty } \\
\text { Acids }\end{array}$} & \multirow{3}{*}{$\begin{array}{c}\text { Control } \\
\text { Mean* } \pm \text { S.E. } \\
* *\end{array}$} & \multicolumn{3}{|c|}{ Exposed snails to miracidia after } \\
\hline & & 10 days & 20 days & 30 days \\
\hline & & Mean* \pm S.E. $* *$ & Mean* \pm S.E. $* *$ & Mean* \pm S.E. $* *$ \\
\hline C12:0 & - & $0.98 \pm 0.08 \mathrm{a}$ & - & $1.84 \pm 0.14 \mathrm{a}$ \\
\hline $\mathrm{C} 13: 0$ & $1.67 \pm 0.09 \mathrm{a}$ & $0.63 \pm 0.56 \mathrm{~b}$ & $1.63 \pm 0.10 \mathrm{a}$ & $1.60 \pm 0.12 \mathrm{a}$ \\
\hline $\mathrm{C} 14: 0$ & $5.67 \pm 0.52 \mathrm{a}$ & $2.35 \pm 0.25 b$ & $5.86 \pm 0.49 a$ & $10.58 \pm 0.92 \mathrm{c}$ \\
\hline $\mathrm{C} 15: 0$ & $1.45 \pm 0.09 \mathrm{a}$ & $1.18 \pm 0.13 \mathrm{a}$ & $1.77 \pm 0.13 \mathrm{a}$ & $1.51 \pm 0.12 \mathrm{a}$ \\
\hline C16:0 & $20.06 \pm 1.22 \mathrm{a}$ & $16.43 \pm 1.06 \mathrm{~b}$ & $26.48 \pm 1.35 \mathrm{c}$ & $33.01 \pm 0.30 \mathrm{~d}$ \\
\hline C17:0 & $1.84 \pm 0.10 \mathrm{a}$ & $0.90 \pm 0.82 b$ & $0.43 \pm 0.38 b$ & $1.80 \pm 0.16 \mathrm{a}$ \\
\hline C18:0 & $8.34 \pm 0.75 \mathrm{a}$ & $8.65 \pm 0.75 a$ & $10.70 \pm 0.95 b$ & $7.27 \pm 0.68 \mathrm{a}$ \\
\hline$\sum$ SFA & $39.40 \pm 1.52 \mathrm{a}$ & $31.12 \pm 1.42 \mathrm{~b}$ & $46.87 \pm 1.85 \mathrm{c}$ & $57.61 \pm 2.04 d$ \\
\hline $\mathrm{C} 16: 1 \omega 7$ & $5.64 \pm 0.48 \mathrm{a}$ & $11.88 \pm 0.95 b$ & $8.52 \pm 0.74 \mathrm{c}$ & $5.10 \pm 0.48 \mathrm{a}$ \\
\hline $\mathrm{C} 18: 1 \omega 9$ & $10.46 \pm 0.94 a$ & $24.20 \pm 1.23 b$ & $12.60 \pm 1.04 \mathrm{a}$ & $10.26 \pm 0.92 \mathrm{a}$ \\
\hline 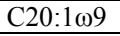 & $2.64 \pm 0.21 \mathrm{a}$ & $2.70 \pm 0.21 \mathrm{a}$ & $0.80 \pm 0.72 b$ & $1.97 \pm 0.18 \mathrm{c}$ \\
\hline $\mathrm{C} 22: 1 \omega 9$ & $2.81 \pm 0.22 \mathrm{a}$ & $1.50 \pm 0.11 \mathrm{~b}$ & - & - \\
\hline$\sum$ MUFA & $21.60 \pm 1.35 \mathrm{a}$ & $40.28 \pm 1.42 b$ & $21.92 \pm 1.26 \mathrm{a}$ & $17.33 \pm 1.10 \mathrm{c}$ \\
\hline $\mathrm{C} 18: 2 \omega 6$ & $16.43 \pm 1.48 \mathrm{a}$ & $9.37 \pm 0.64 b$ & $13.11 \pm 1.16 \mathrm{c}$ & $7.22 \pm 0.72 \mathrm{~d}$ \\
\hline $\mathrm{C} 18: 3 \omega 3$ & $8.67 \pm 0.72 \mathrm{a}$ & $11.00 \pm 1.14 \mathrm{~b}$ & $11.72 \pm 0.98 \mathrm{c}$ & $5.17 \pm 0.56 \mathrm{~d}$ \\
\hline $\mathrm{C} 20: 2 \omega 6$ & $2.54 \pm 0.22 \mathrm{a}$ & $2.32 \pm 0.34 a$ & $0.42 \pm 0.36 b$ & $3.40 \pm 0.39 \mathrm{c}$ \\
\hline 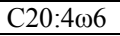 & $0.81 \pm 0.08 \mathrm{a}$ & $1.92 \pm 0.21 b$ & $1.47 \pm 0.14 b$ & $4.40 \pm 0.32 c$ \\
\hline $\mathrm{C} 20: 5 \omega 3$ & $6.86 \pm 0.47 \mathrm{a}$ & $1.13 \pm 0.08 \mathrm{~b}$ & $5.60 \pm 0.49 a$ & $3.46 \pm 0.35 c$ \\
\hline $\mathrm{C} 22: 2 \omega 6$ & $3.25 \pm 0.22 \mathrm{a}$ & $2.41 \pm 0.12 \mathrm{a}$ & $1.47 \pm 0.10 \mathrm{~b}$ & $2.20 \pm 0.23 a$ \\
\hline $\mathrm{C} 22: 6 \omega 3$ & $2.12 \pm 0.23$ & - & - & - \\
\hline$\sum$ PUFA & $39.98 \pm 1.53 \mathrm{a}$ & $28.15 \pm 1.34 b$ & $31.68 \pm 1.42 \mathrm{c}$ & $25.50 \pm 1.32 \mathrm{~d}$ \\
\hline
\end{tabular}

Table 4: Total fatty acid contents in B. alexandrina infected with $S$. mansoni

\begin{tabular}{|c|c|c|c|c|}
\hline \multirow{2}{*}{$\begin{array}{c}\text { Fatty } \\
\text { Acids }\end{array}$} & \multirow{2}{*}{$\begin{array}{c}\text { Control } \\
\text { Mean* } \pm \text { S.E. ** }\end{array}$} & \multicolumn{3}{|c|}{ Exposed snails to miracidia after } \\
\cline { 3 - 5 } & & 10 days & 20 days & 30 days \\
\cline { 2 - 5 } & & Mean* \pm S.E. ** & Mean* \pm S.E. ** & Mean* \pm S.E. ** \\
\hline \multirow{3}{*}{$\sum$ SFA } & $32.55 \pm 1.42 \mathrm{a}$ & $29.24 \pm 1.31 \mathrm{a}$ & $39.22 \pm 1.65 \mathrm{~b}$ & $45.32 \pm 1.75 \mathrm{c}$ \\
\cline { 2 - 5 } & $35.42 \pm 1.33 \mathrm{a}$ & $30.43 \pm 1.50 \mathrm{a}$ & $48.39 \pm 2.33 \mathrm{~b}$ & $50.89 \pm 2.50 \mathrm{~b}$ \\
\cline { 2 - 5 } & $39.00 \pm 1.42 \mathrm{a}$ & $30.15 \pm 1.42 \mathrm{~b}$ & $47.67 \pm 1.65 \mathrm{c}$ & $58.81 \pm 2.14 \mathrm{~d}$ \\
\hline \multirow{3}{*}{$\sum$ MUFA } & $40.37 \pm 1.42 \mathrm{a}$ & $40.41 \pm 1.75 \mathrm{a}$ & $34.45 \pm 1.49 \mathrm{~b}$ & $20.09 \pm 1.23 \mathrm{c}$ \\
\cline { 2 - 5 } & $31.34 \pm 1.32 \mathrm{a}$ & $45.57 \pm 2.30 \mathrm{~b}$ & $23.31 \pm 1.21 \mathrm{c}$ & $17.61 \pm 1.21 \mathrm{~d}$ \\
\cline { 2 - 5 } & $24.30 \pm 1.35 \mathrm{a}$ & $40.28 \pm 1.42 \mathrm{~b}$ & $20.82 \pm 1.22 \mathrm{a}$ & $18.33 \pm 1.12 \mathrm{c}$ \\
\hline \multirow{3}{*}{$\sum$ PUFA } & $28.56 \pm 1.25 \mathrm{a}$ & $28.33 \pm 1.36 \mathrm{a}$ & $27.59 \pm 1.23 \mathrm{a}$ & $36.58 \pm 1.45 \mathrm{~b}$ \\
\cline { 2 - 5 } & $36.13 \pm 1.28 \mathrm{a}$ & $20.95 \pm 1.39 \mathrm{~b}$ & $27.68 \pm 1.32 \mathrm{c}$ & $34.60 \pm 1.36 \mathrm{a}$ \\
\cline { 2 - 5 } & $40.18 \pm 1.43 \mathrm{a}$ & $26.15 \pm 1.24 \mathrm{~b}$ & $31.68 \pm 1.42 \mathrm{c}$ & $24.50 \pm 1.22 \mathrm{~d}$ \\
\hline
\end{tabular}

\section{Discussion}

As a source of energy, neutral lipids are extremely important in pulmonate snails during the course of schistosome infection (Duncan et al, 1987; Stuart and Ballantyne, 1996; Kobucar et al, 1997). Triacylglycerols, the component lipids, are initially hydrolyzed to free fatty acids which are, in turn, oxidized in the fatty acid cycle within the mito- chondrial matrix (Voogt, 1984; Tripathi and Singh, 2002). Fatty acids detected in total body lipids, phospholipid, and neutral lipid fractions from infected and uninfected $B$. alexandrina include C10:0, C12:0, C13:0, C14:0, C15:0, C16:0, C17:0, C18:0 SFAs;

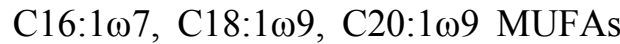
\& $\mathrm{C} 18: 2 \omega 6, \mathrm{C} 18: 3 \omega 3, \mathrm{C} 20: 2 \omega 6, \mathrm{C} 20$ : $3 \omega 6, \mathrm{C} 20: 4 \omega 6, \mathrm{C} 20: 5 \omega 3, \mathrm{C} 22: 2 \omega 6$, 
C22:6 63 PUFAs. Fatty acids are very common in marine and freshwater mollusks (Pollero et al, 1983).

Lipids have many functions in biological systems, energetic and structural. In snails it has been identified that the lipids are involved in the animals survival under the physiological stress conditions, such as long food restriction or when the snails are parasitized, when the carbohydrates reserves are quickly depleted and the lipids are consumed more frequently and changes in different kinds of lipids are observed (Storey, 2002; Giokas et al, 2005; Bandstra, 2006a). They are structural components of biological membranes and alterations on number and composition of thelipids may happen when changes in the metabolic state of the snails occur in response to stress factors (Stuart et al, 1998a, b).

The lipid contents in the snails assayed after 10 days post infection were evidently smaller than those in the control. The lipid contents became clearly lower as the infection proceeded. For example, the digestive gland of those snails examined after 20 days post infection showed extensive reduction as a result of the activities of the sporocysts and cercariae present; the content of lipid was much lower than that in the control. Similar patterns were observed for lipid content in the digestive gland of the snails examined after 30 days post infection.

The present results revealed that the qualitatively most important fatty acids in gastropods are similar in B. alexandrina and fatty acid profiles of the snail conform to the common pattern, char- acteristic of gastropods in general (Pollero et al, 1981; 1983; Storey, 2002; Giokas et al, 2005). In the present analyses, C16:0, C18:0, C18:1 $\omega 9$ and $\mathrm{C} 18: 2 \omega 6$ acids were major components. Small proportions of C10:0, C12:0, $\mathrm{C} 13: 0, \mathrm{C} 22: 2 \omega 6$, and $\mathrm{C} 22: 6 \omega 3$ acids were also found. Similar findings were also reported in other works (Dembitsky et al, 1992; Abad et al, 1995; Misra et al, 2002; Fried et al, 2001; Go et al, 2002). Temperature, food availability, and metabolic and physiological activities can affect the lipid and fatty acids composition of mollusks (Misra et al, 1985; Abad et al, 1995; 2002). In this study, the statistical analyses revealed significant differences in $\Sigma$ SFA, ${ }_{\Sigma}$ MUFA $\&_{\Sigma}$ PUFA levels in $B$. alexandrina.

Mollusks stored lipids for reproductive purposes (Bandstra et al, 2006a); however, they provide energy during winter, when carbohydrate reserves are depleted (Bandstra et al, 2006b). So, fatty acid composition of snail, neutral lipids in particular, is dictated by snail's metabolic activities which were affected by the presence of schistosome parasite within the snails. The parasites obtain energy predominantly by catabolism of carbohydrates (Barret and Saghir, 1999), so they deplete the hosts' carbohydrate reserves at the onset of infection, while the snails draw energy by decomposing lipids. This is very plausible, particularly in view of the fact that lipids are virtually the sole energy source in numerous fasting or hibernating animals. A parasitic infection confronts an organism with a situation resembling that of fasting (Dun- 
kan et al, 1987). The loss of lipids in the digestive gland of the parasite infected snails is evidence that the snails mobilize energy resources accumulated in that form to compensate for the loss of carbohydrates in these parasites.

The triacylglycerols store SFAs for energy purposes and they also may be temporary PUFAs reservoir (Ackman, 1983; Napolitano et al, 1992), which could be transferred to structural lipids or directed to specific metabolic pathways. In contrast, phospholipid fractions of mollusks show considerably less seasonal variation to maintain structural integrity of the cell as compared to neutral lipids (Chu and Greaves, 1991).

The loss of lipids in the digestive gland of the infected snails points at mobilization of lipid energy reserves to compensate for the deficiency of carbohydrates, used by these parasites. As a source of energy, neutral lipids are extremely important in pulmonate snails (Duncan et al, 1987; Stuart and Ballantyne, 1996; Kobucar et al, 1997). The results showed that the digestive glands parasitized by $S$. mansoni are reduced in amount of neutral (storage) lipids. Humiczewska and Rajsk, (2005) reported that carbohydrate levels were greatly reduced during a parasitic infection that agreed with others (Jarusiewicz et al., 2006).

\section{Conclusion}

Schistosomiasis is still to be complicated unsolved health problem encountering medical, socio-economic and behavioral parameters worldwide. The severity of risk factors for schistosomiasis infection depends basically on the concentration of cercariae population coming out of snails in natural water bodies. Besides, freshwater snails serve as intermediate host for risky zoonotic trematodes.

The outcome results showed that the loss of lipids in the digestive gland of the infected snails point at mobilization of lipid energy reserves to compensate for the deficiency of carbohydrates, used by these parasites and the concentration of triacylglycerols in the infected digestive gland-gonad complex was significantly less than that of the uninfected.

\section{Acknowledgements}

This study was kindly financial support by the Internal Research Project No. 98C, Theodor Bilharz Research Institute. The experiments described in this work comply with the current research laws of Egypt.

\section{References}

Abad, M, Ruiz, C, Martinez, D, et al, 1995: Seasonal variation of lipid classes and fatty acids in flat oyster Ostrea edulis from San Cibrian (Galicia, Spain). Comp. Biochem. Physiol. 110C: 109-18.

Ackman RG, 1983: Fatty acids metabolism of bivalves. In: Biochemical and Physiological Approaches to Shellfish Nutrition. Proceed. $2^{\text {nd }}$ Int. Conf. Aquaculture Nutrition: World Mariculture Society Specific Publication. No 2, Louisiana State University, Louisiana.

Bandstra, SR, Fried, B, Sherma J, 2006a: A review: Effects of diet and larval trematode parasitism on lipids in snails as determined by thin layer chro- 
matography. J. Planar. Chromatogr. Mod. TLC 19:180-6.

Bandstra, SR, Fried, B, Sherma J, 2006b: High-performance thin-layer chromatographic analysis of neutral lipids and phospholipids in Biomphalaria glabrata patently infected with Echinostoma caproni. Parasitol. Res. 99, 4:414-8.

Barrett, J, Saghir N. 1999: Lipid binding proteins in parasitic helminths.

Res. Rev. Parasitol. 59:107-12.

Beers, K, Fried, B, Fujino, T, Sherma,J, 1995: Effects of diet on the lipid com-position of the digestive glandgonad complex of Biomphalaria glabrata (Gas-tropoda) infected with larval Echinostoma caproni (Trematoda). Comp.Biochem. Physiol.110B:729-37.

Chu, FLE, Greaves J, 1991: Metabolism of palmitic, linoleic and linolenic acids in adult oysters. Crassostrea virginica. Mar. Biol. 110:229-36.

Dembitsky, VM, Kashin, AG, Stefanow, K, 1992: Comparative investigation of phospholipids and fatty acids of freshwater molluscs from Volga River Basin. Comp. Biochem. Physiol. 102B: 193-8.

Duncan, M, Fried, B, Sherma, JI, 1987: Lipids in fed and starved $B i$ omphalaria glabrata (Gastropoda). Comp.Biochem. Physiol. 86A:663-5.

Faust, EC, 1917: Life history studies on Montana trematodes. Illinois Biological Monographs 4:1-121.

Folch, J, Lees, M, Sloane-Stanley, GH, 1957: A simple method for the isolation and purification of total lipids from animal tissues. J. Biol. Chem. 226:497-509.
Fried, B, Muller, EE, Broadway, A, Sherma, J, 2001: Effects of diet on the development of Schistosoma mansoni in Biomphalaria glabrata and on the neutral lipid content of the digestive gland-gonad complex of the snail. J. Parasitol. 87: 223-5

Fried, B, Schafer, S, Kim, S, 1989: Effects of Echinostoma caproni infection on the lipid-composition of Biomphalaria glabrata. Int. J. Parasitol. 19:353-4.

Fried, B, Sherma, J, 1990: Thin layer chromatography of lipids found in snails (Gastropoda: Mollusca). J. Planar. Chromatogr. 3:290-9.

Giokas, S, Pafilis, P, Valakos, E, 2005: Ecological and physiological adaptations of the land snail Albinaria caerulea (Pulmonata: Clausiliidae). J. Mollus. Studies 71, 1:15-23.

Go, JV, Rezanka, T, Srebnik, M, et al, 2002: Variability of fatty acid component of marine and freshwater gastropod species from the littoral zone of the Red Sea, Mediterranean Sea and Sea of Galilee. Biochem. Syst. Ecol. 30:819-35.

Humiczewska, M, Rajski, K, 2005: Lipids in the host-parasite system: digestive gland of Lymnaea truncatula infected the developmental stages of Fasciola hepat-ica. Acta Parasitol. 50:235-9.

Jarusiewicz JA, Sherma J, Fried B. 2006: Thin layer chromatographic analysis of glucose and maltose in estivated Biomphalaria glabrata snails and those infected with Schistosoma mansoni. Comp. Biochem. Physiol. Mol. Biol. 145:346-9. 
Klobucar, GIV, Lajtner, J, Erben, R, 1997: Lipid peroxidation a histopathological changes in the digestive gland of a freshwater snail Planorbarius corneus L. (Gastropoda, Pulmonata) exposed to chronic and sub-chronic concentrations of PCP. Bull. Environ. Contamin. Toxicol. 58:128-34

Massa DR, Chejlava, MJ, Fried, B, Sherma J. 2007: High performance column liquid chromatographic analysis of selected carboxylic acids in Biomphalaria glabrata patently infected with Schistosoma mansoni. Parasitol Res. 101, 4:925-8.

Misra, KK, Ghosh, KM, Choudhury, A et al, 1985: Fatty acids from Macoma sp. of bivalve mollusc. J. Sci. Food Agric. 36:1193-6.

Misra, KK, Shkrob, I, Rakshit, S, et al, 2002: Variability in fatty acids and fatty aldehydes in different organs of two prosobranch gastropod molluscs. Biochem. Syst. Ecol. 30:749-61.

Muller, EE, Fried, D, Sherma, J, 2000: HPTLC analysis of neutral lipids in Biomphalaria glabrata snails infected with Schistosoma mansoni (Trematoda). J. Planar. Chromatogr. Mod. TLC 13:228-31.

Napolitano, GE, MacDonald, BA, 1992: Thompson RJ et al. Lipid composition of eggs and adductor muscle in giant scallops (Plactopectenma gellanicus) from different habitats. Mar. Biol. 113:71-6.

Perez, MK, Fried, B, Sherma, J, 1994: Comparison of mobile phases \& HPTLC qualitative and quantitative analysis, on spread sorbent silica gel plates of phospholipids in Biomphalaria glabrata (Gastropoda) infected with Echinostoma caproni (Trematoda). J. Planar. Chromatogr. Mod. TLC 7:3403.

Pollero, RJ, Irazu, CE, Brenner, RR, 1983: Effect of sexual stage on lipids and fatty acids of Diplodond elodontus. Comp. Biochem. Physiol. 76B:927-31.

Storey, KB, 2002: Life in the slow lane: Molecular mechanisms of estivation. Comp. Biochem. Physiol. 133, 3: 733-54.

Stuart JA, Ballantyne JS, 1996: Subcellular organization of intermediary metabolism in the hepatopancreas of the terrestrial snail, Cepaeane moralis: A cytosolic beta-hydroxybutyrate dehydrogenase. J. Exp. Zool. 274:291-9.

Stuart, JA, Gillis, TE, Ballanyne, JS, 1998a: Compositional correlates of metabolic depression in the mitochondrial membranes of estivating snails.

Amer. J. Physiol. Regulat. Integrat. Comp. Physiol. 44, 6:1977-82

Stuart, JA, Gillis, TE, Ballanyne, JS, 1998b: Remodeling of phospholipid fatty acids in mitochondrial membranes of estivating snails. Lipids 33, 8:87-93.

Thompson, SN, 1997: Physiology and biochemistry of snail-larval trematode relationships. In: Advances in Trematode Biology. Fried, B, Graczyk, TK, editors. Florida, USA: CRC Press.

Tripathi, PK, Singh, A, 2002: Toxic effects of dimethoate and carbaryl pesticides on carbohydrate metabolism of freshwater snail Lymnaea acuminata. Bull. Environ. Contam. Toxicol. 68: 606-11

Tunholi-Alves, VM, Tunholi, VM, Gôlo, P, Lustrino, D, Maldonado, A, 
et al, 2011: Lipid levels in Biomphalaria glabrata infected with different doses of Echinostoma paraensei miracidia. Exp. Parasitol. 128, 3:212-6.
Voogt, PA, 1984: Lipids: their distribution and metabolism. In: The Mollusca, by Hochachka, PW, $1^{\text {st }}$ edition, Academic Press, New York. 